\title{
Isoforms of Mammalian Cytochrome c Oxidase: Correlation with Human Cytochrome c Oxidase Deficiency
}

\author{
NANCY G. KENNAWAY, ROQUE D. CARRERO-VALENZUELA, GARY EWART, \\ VIJAY K. BALAN, ROBERT LIGHTOWLERS, YU-ZHONG ZHANG, BERKLEY R. POWELL, \\ RODERICK A. CAPALDI. AND NEIL R. M. BUIST \\ Departments of Medical Genetics [N.G.K., R.D.C.-V., V.K.B., N.R.M.B.] and Pediatrics [B.R.P., N.R.M.B.], \\ Oregon Health Sciences University, Portland, Oregon 97201 and Institute of Molecular Biology /G.E., R.L., \\ Y-Z.Z. R.A.C.J. University of Oregon, Eugene, Oregon 97403
}

\begin{abstract}
We have reviewed the structure, function, and biogenesis of mammalian cytochrome c oxidase, examined the tissue-specific expression of isoforms of cytochrome c oxidase subunits in different mammals, and attempted to correlate the data with our knowledge of cytochrome c oxidase deficiency, illustrated by one particular patient. Cytochrome c oxidase was isolated from bovine tissues, and individual subunits examined by SDS-PAGE, $\mathrm{N}$-terminal peptide sequencing, and antibody binding. Isoforms of subunits VIa, VIIa, and VIII were identified, manifesting one pattern of expression in heart and skeletal muscle, and another in liver, kidney, and brain. In rat heart and liver, only one form of subunit VIIa was identified. Northern analysis of bovine and rat tissues suggested that the tissue-specific expression of subunits VIa and VIII is regulated transcriptionally in liver, kidney, and brain, and posttranscriptionally in heart and skeletal muscle. In humans, antibody binding documented isoforms of subunits VIa and VIIa, with the pattern of expression in heart and skeletal muscle differing from that in liver, kidney, and brain; our data suggested that both isoforms of subunit VIa may be expressed in human heart. In a patient with cytochrome c oxidase deficiency, the clinical, morphologic, and biochemical manifestations were much more severe in heart than in skeletal muscle. Antibody binding suggested partial assembly of the enzyme in heart. These and other data suggest considerably more variability in the tissue-specific expression of isoforms of cytochrome $c$ oxidase subunits than previously recognized. (Pediatr Res 28: 529-535, 1990)
\end{abstract}

Abbreviations

mtDNA, mitochondrial DNA

Over the past few years, there has been increasing recognition of the importance of inherited disorders of the mitochondrial respiratory chain in a wide variety of human diseases (1). Disorders of complex I (NADH:ubiquinone oxidoreductase) (2), complex II (succinate:ubiquinone oxidoreductase) (3), complex III (ubiquinol:cytochrome c oxidoreductase) (4), and complex

Correspondence and reprint requests: Dr. Nancy G. Kennaway, Department of Medical Genetics/L473. Oregon Health Sciences University, 3181 S.W. Sam Jackson Park Rd.. Portland. OR 97201-3098.

Supported in part by NIH Grant 22050, a grant from the Muscular Dystrophy Association. and a grant from the Medical Research Foundation of Oregon.
IV (cytochrome c oxidase) (5) have all been described. The severity of these disorders is very variable, and the spectrum of clinical disease is impressive, ranging from isolated myopathy or cardiomyopathy in some patients to a multisystem disease such as Leigh's syndrome in others. This variability presumably results in part from the complexity of the respiratory chain proteins, the smallest of which (complex II) comprises four or five individual subunits, and the largest of which (complex I) comprises at least 26 individual subunits (6). Some of these subunits appear as tissue-specific isoforms in mammals.

The identification of patients with respiratory chain deficiencies limited to one or a few tissues suggests that isoforms of some of these proteins may also exist in humans and provide an explanation for the tissue-specific expression of the disease in such patients. Until very recently, attempts to define the tissue specificity of the respiratory chain have focused mainly on beef and rat, not only because of the ready availability of tissue material, but also because of the assumption that the pattern of expression of these isoforms would be conserved in all mammals, including humans. There is preliminary evidence of isoforms of some subunits of complex I (7); however, the most comprehensive data have been obtained on cytochrome $\mathrm{c}$ oxidase. In this report we will: $I$ ) review the structure, function, and biogenesis of mammalian cytochrome $\mathrm{c}$ oxidase; 2 ) discuss the tissue specificity and expression of isoforms of cytochrome c oxidase in mammals, including humans; and 3 ) relate this briefly to the phenotypes of cytochrome c oxidase deficiency, and to one patient that we have studied recently in particular.

\section{CYTOCHROME c OXIDASE: TERMINAL OXIDASE IN RESPIRATION}

Structure, function, and biogenesis. Cytochrome c oxidase, the terminal component of the respiratory chain, spans the mitochondrial inner membrane and transfers electrons from reduced cytochrome $\mathrm{c}$ to molecular oxygen with generation of a transmembrane proton gradient. In mammals, the enzyme is a multicomponent complex containing 13 different polypeptides (8). The three largest subunits are coded on mtDNA and synthesized in the mitochondrion. These mitochondrially-coded subunits appear to be the functional core of the enzyme, but the function(s) of the nuclear coded subunits is presently unclear. Figure 1 shows the resolution of all the subunits of beef heart cytochrome c oxidase on highly resolving SDS-PAGE and presents two nomenclatures currently in use for the different subunits; the nomenclature of Kadenbach et al. (9) is used in this review.

The biosynthesis of cytochrome $c$ oxidase is complicated, involving components coded on two genomes and synthesized 


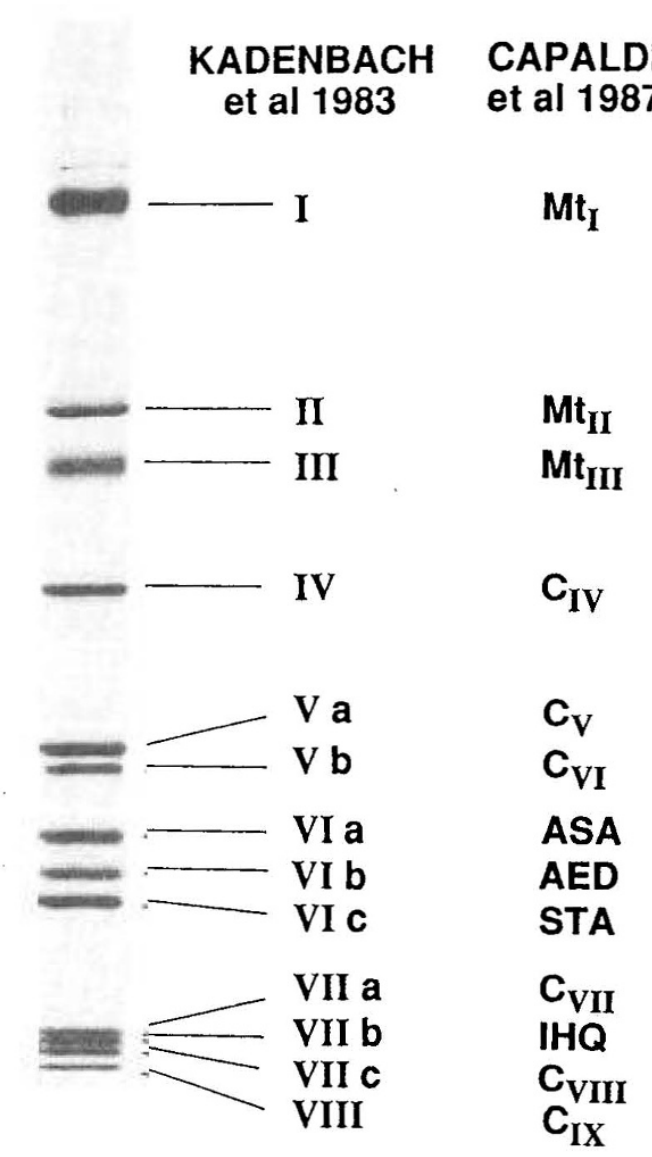

Fig. 1. Subunit structure of beef heart cytochrome c oxidase, showing two nomenclatures currently in use $(9,10)$. The enzyme was purified from mitochondrial preparations essentially as described (11), subunits separated on an $18.5 \%$ polyacrylamide gel containing $6 \mathrm{M}$ urea (9), and proteins stained with Coomassie Brilliant Blue.

in two compartments, namely the mitochondrial matrix and the cytoplasm. This overall process is shown schematically in Figure 2 . Briefly, nuclear coded subunits, synthesized on free ribosomes, are released in the cytoplasm as precursor proteins, frequently containing an $\mathrm{N}$-terminal extension or leader peptide that targets the protein to the mitochondrion and that may help direct the protein to the correct location within the organelle, i.e. intracristal space, inner membrane, or matrix. Mitochondrially synthesized proteins are transcribed as a polycistronic message that is processed to give mRNA for individual subunits. The three subunits of cytochrome $\mathrm{c}$ oxidase are synthesized as mature polypeptides in mammals and may be cotranslationally inserted into the mitochondrial inner membrane. Steps involved in the addition of heme and coppers to subunits I and II have not been identified yet, but may occur at the inner membrane concurrent with the assembly of the mitochondrially and nuclear coded subunits into the complex.

\section{ISOFORMS OF MAMMALIAN CYTOCHROME c OXIDASE}

The occurrence of tissue-specific isoforms of mammalian cytochrome c oxidase was first suggested by Kadenbach et al. (13), based on slight differences in the apparent molecular weight of some subunits in different tissues from each of several species including rat, pig, chicken, and beef. We have focused our attention on tissue-specific variation of subunits of this enzyme in beef, where extensive protein sequence data of the heart enzyme was available already, and in humans, as part of our program on mitochondrial diseases. A review of our current understanding of tissue specificity of cytochrome c oxidase in these different animals follows.

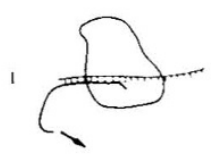

CYTOPLASM
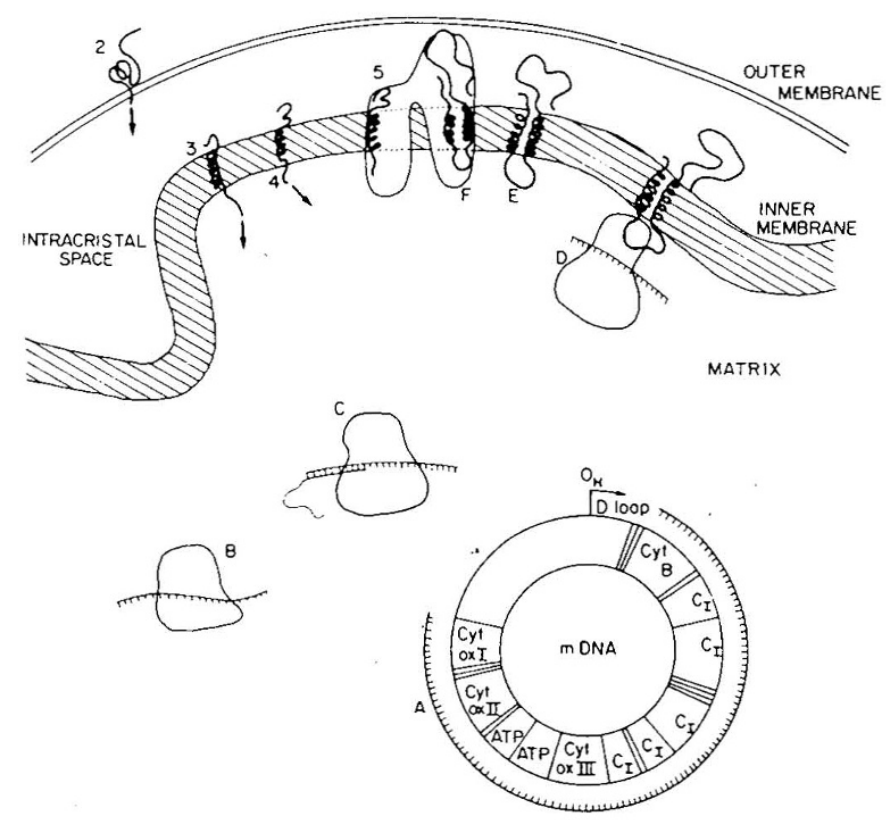

Fig. 2. Schematic representation of the synthesis and assembly of the respiratory chain complexes in mammals. Reproduced from Takamiya et al. (12), with permission.

Rat. In their original experiments, Merle and Kadenbach (14) found an altered migration of subunit VIa when the composition of the heart and liver enzyme was compared by SDS-PAGE (14). The presence of isoforms of subunit VIII as well as VIa was indicated by differences in labeling of these two subunits in different tissues by sulfhydryl reagents (15). Characterization of two cDNA, one isolated from a rat liver, the other from a rat heart cDNA library, offers definitive evidence that there are two forms of subunit VIa (16). The two forms of subunit VIa encoded by these cDNA show only $50 \%$ homology. The expression of the isoforms of subunit VIa was explored by Schlerf et al. (16) using Northern analysis; the heart form of this subunit was found to be transcribed in heart and skeletal muscle only but, surprisingly, the liver form was transcribed in all tissues examined (16).

More recently, Kuhn-Nentwig and Kadenbach (17) have used quantitative immunoassays to compare subunits from a variety of adult and fetal rat tissues. Based on these studies, they have concluded that all of the nuclear coded subunits of cytochrome c oxidase may occur in different tissue-specific forms in mammals, that more than three different isoforms are present for many subunits, and that there are major differences between fetal and adult tissues. However, these results are open to question, because some of the observed antigenic differences may have resulted from acquired conformational differences such as the extent of denaturation of the same subunit from different tissues.

The early data of Kadenbach et al. (13) showed no difference in the migration of cytochrome $c$ oxidase subunit VIIa in rat heart and liver by SDS-PAGE, in contrast to what was seen in some other mammals (13). We have recently obtained preliminary data also suggesting that isoforms of subunit VIIa may not occur in rat. Figure 3 shows the $\mathrm{N}$-terminal sequence data on this subunit from rat heart and rat liver and compares these data with the sequences of the two isoforms of this subunit in beef. The rat sequences are identical at several positions in which the two isoforms in beef are different. This suggests an important difference in the tissue-specific pattern of isoforms of cytochrome 


$\begin{array}{ll}\text { RATHEART } & \text { F E N K V P E K Q K L F Q E D N G M P V H L K G } \\ \text { RATLIVR } & \text { F E N K V P E K Q K L F Q E D N G M P V H L } \\ \text { BEEFHEART } & \text { F E N R V A K K Q K L F Q E D N G L P V H L K G } \\ \text { BEEF LIVER } & \text { F E N K V P E K Q K L F Q E D N G I P V H L K G }\end{array}$

Fig. 3. N-terminal sequences of subunit VIIa of cytochrome c oxidase from rat and beef tissues. After electrophoresis of purified enzyme (as described in Figure 1), subunits were transferred to polyvinylidene difluoride membranes as described (18). After staining, the blots were air dried and stored at $-20^{\circ} \mathrm{C}$. Polypeptides of interest were cut from the membrane and sequenced in a gas phase protein sequencer equipped with an online phenylthiohydantoin analyzer.

c oxidase in rat compared with other mammals such as beef, described in more detail below.

Beef. Our studies of the beef enzyme began with a comparison of the subunits of liver cytochrome c oxidase with those of the heart enzyme, for which sequence data were available (19). Subunits IV, Va, Vb, VIb, VIc, VIIb, and VIIc in liver all had the same N-terminal sequences as those for heart and, to date, we have no evidence for isoforms of any of these subunits. However, any of these subunits may have a second isoform, differing in only a few amino acids at the $\mathrm{C}$ terminus, and there may be as yet unidentified isoforms of any subunit present in low amounts in one or more tissues that are not identified by protein chemical analysis of the isolated enzyme.

Three subunits, VIa, VIIa, and VIII, migrated differently when heart and liver enzyme were compared by SDS-PAGE (19). Nterminal sequencing of the liver forms of these three subunits showed homologies, but many amino acid differences, compared to the corresponding heart subunits. We have since cloned cDNA encoding the heart form and liver form of subunit VIII; the mature proteins show only $52 \%$ homology to each other and the leader sequences only $40 \%$ homology (20). The differences in the two isoforms reside mainly in the $\mathrm{N}$-terminal hydrophilic part of the polypeptides.

Recently, we have examined the subunit profile of cytochrome $c$ oxidase from a number of bovine tissues. The migrations of subunits VIa, VIIa, and VIII in skeletal muscle are the same as in heart, and the migrations of these three subunits in kidney (not shown) and brain are the same as in liver (Fig. 4). Nterminal sequence analysis demonstrates clearly that brain and kidney isoforms of these subunits differ from their counterparts in heart, and that the skeletal muscle isoforms differ from those in liver. The results also suggest that the heart and muscle isoforms are identical, as are those of liver, kidney, and brain (Fig. 5). Although protein sequencing identifies the main isoform of a particular subunit, it does not preclude the presence of small amounts of the alternative isoform in the same tissue. We excluded this possibility for the heart isoform of subunit VIa in tissues other than heart and skeletal muscle, using a MAb specific to the beef heart isoform. As seen in Figure 6, there is no detectable cross-reactivity with cytochrome c oxidase from beef liver, kidney, or brain, thus excluding the presence of small amounts of the heart isoform in these tissues.

Northern analysis using cDNA for the two isoforms of rat subunit VIa (kindly provided by Dr. B. Kadenbach) showed that, as in rat, the mRNA for the $\mathrm{H}$ form of this subunit is present in bovine heart and skeletal muscle only, but the $\mathrm{L}$ form is present in all tissues (data not shown). The same pattern of expression was found for subunit VIII: the $\mathrm{H}$ form is only present in heart and skeletal muscle tissue, whereas the $\mathrm{L}$ form is present not only in brain, liver, and kidney, but in heart and skeletal muscle as well (Fig. 7) (20). However, the subunit profiles of cytochrome c oxidase (Fig. 4) show little or no incorporation of the L form of subunit VIII into functional enzyme in heart or muscle, a result confirmed by careful analysis including protein sequencing studies (20). These data suggest that the expression of the $\mathrm{H}$ isoform of cytochrome c oxidase is controlled transcriptionally but the expression of the $\mathrm{L}$ isoform is regulated posttranscriptionally.

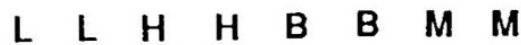

I

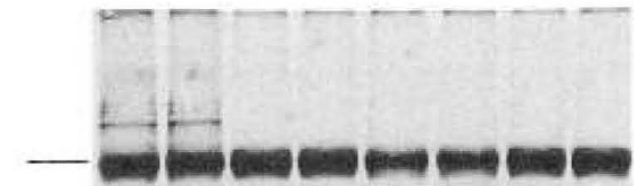

II

III

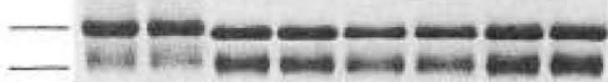

IV

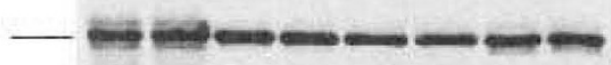

$\mathrm{V}$ a

$\mathrm{Vb}$

VI a

VI b

VI c

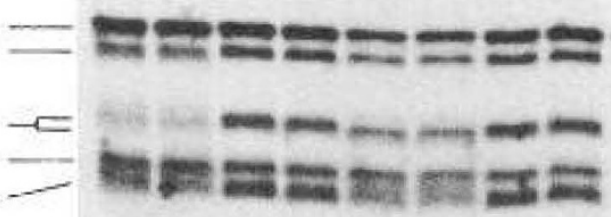

VII a

VII b, c

VIII

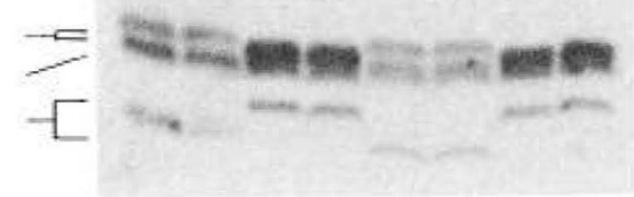

Fig. 4. Comparison of the subunit structure of beef liver $(L)$, heart $(H)$. brain $(B)$, and skeletal muscle $(M)$ cytochrome $\mathrm{c}$ oxidase, showing differences in migration of subunits VIa, VIIa, and VIII. Methods as in Figure 1, except that subunits were separated on a $18.75 \%$ polyacrylamide gel containing $6 \mathrm{M}$ urea.

Humans. Our knowledge of the tissue specificity of human cytochrome c oxidase is rudimentary. We have found that a majority of the polyclonal antibodies and several of the MAb made against the bovine enzyme subunits react with human cytochrome c oxidase. Figure 8 shows a typical immunologic experiment in which mitochondria from different tissues were treated with subunit-specific antibodies using the Western blotting technique.

The polyclonal antibody to subunit VIa reacts well with isolated beef heart cytochrome $c$ oxidase but only poorly with the beef liver enzyme, establishing that this antibody can distinguish between the $\mathrm{H}$ and $\mathrm{L}$ isoforms. In humans, the antibody reacts strongly with heart and skeletal muscle and less well but signifi- 


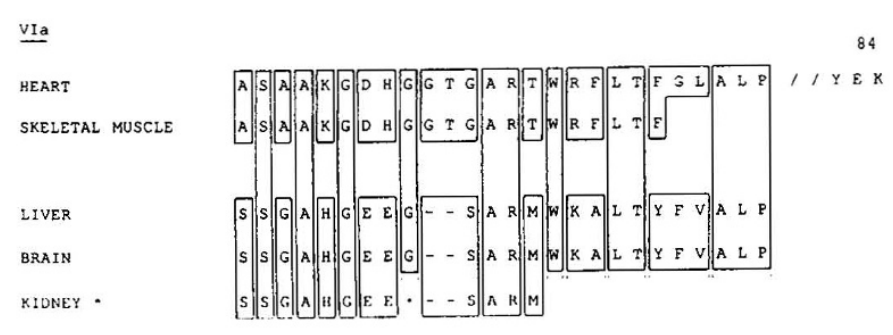

vila

$$
\text { MEART }
$$$$
\text { SKE..ETAL. MUSCLE }
$$

LIVI:R

HRAIN

KIDNFY.

vin!

ME:AKT

SKELLETAL, MUSCLE:

L.IVER

IBKAIN

KIONEY

lïg. 5. N-terminal sequences of subunits VIa, VIla, and VIII from dilferent beef tissues. Methods as in ligure 3.

Cantly with liver, brain, and kidney (taking into account that there are different amounts of cytochrome c oxidase in these different preparations as judged by antibody to subunit IV). It is also apparent that subunit VIa in skeletal muscle migrates slightly more slowly than that in brain, kidney, or liver. Intriguingly, with the anti-Vla antibody, the reactive band in heart is broad, and close inspection of the gel shows two species present, a heavy band comigrating with subunit VIa of muscle and a lighter band comigrating with subunit VIa of liver, brain, and kidney. Although it is possible that the lighter band represents a degradation product of the heart isoform, this is unlikely, inasmuch as it has been seen in several preparations of heart, but not muscle, mitochondria, including some isolated in the presence of protease inhibitors. These data imply that there are at least two isoforms of subunit VIa in human tissues, $\mathrm{H}$ and $\mathrm{L}$ forms, as in beef, with the $\mathrm{H}$ form present in heart and skeletal muscle and the L form found in brain, kidney, and liver, and possibly also in heart.

The antibody against subunit VIla reacts well with beef heart enzyme but very poorly with liver. The anti-VIIa antibody also reacts well with human heart and skeletal muscle but not with liver, kidney, or brain, indicating that in humans there are two isoforms of this subunit with apparently the same tissue distribution as in beef (Fig. 8). Our antibody against bovine heart subunit VIII is one of the few beef antibodies that does not react with the human enzyme, and it was not possible to assess tissue specificity of this subunit immunologically. However, subunit VIII of human heart cytochrome c oxidase has been isolated recently and sequeneed (22). This polypeptide is remarkably similar to bovine liver subunit VIII and much different from the bovine heart isoform. The protein sequence obtained by van Kuilenburg el al. (22) is identical to the predicted product of the cDNA cloned from human liver (23). The migration of subunit VIII from human heart and liver is the same, also suggesting that there may be only one form of subunit VIII in humans.

In summary, there is unequivocal evidence of isoforms of several subunits of cytochrome coxidase in rat, beef, and human.
What is not clear is how many of the nuclear coded subunits have different isoforms or how many isoforms there are of any subunit. Moreover, it remains possible and even likely, given the above data, that the pattern of tissue specificity differs in different mammals. The limited data on humans provide evidence that there are at least two different forms of subunits VIa and VIIa with an $\mathrm{H}$ and an $\mathrm{L}$ form of these subunits, as in beef. More ücininitive resulis wili require the isolation of human cytochrome c oxidase from different tissues and the sequencing of eomponent polypeptides.

Finnclional significance of tissue-specific isoforms of cytochrome' (oxidase. From the above review of the subunit structure of cytochrome c oxidase and the tissue-specific expression of isoforms of some subunits, two questions emerge: $l$ ): What are the functions of the nuclear coded subunits of this enzyme? and 2) What is the advantage of the tissue specificity of some of these subunits?

Several possible roles for the nuclear coded subunits of cytochrome c oxidase have been suggested. These include regulation of the rate of electron transfer or proton pumping function by effectors such as nucleotides or hormones (24). The evidence for this is weak at the moment, although $\Lambda T P$ may alter the affinity of the enzyme for cytochrome $c$ at low concentrations of substrate (25). It is not clear if there is an advantage in the tissue-specific expression of isoforms of eytochrome c oxidase subunits. If there is, it presumably relates to the function of the subunit in the complex. Thus, it seems likely that the tissue-specific expression of these isoforms, and their apparently variable patterns of expression in mammals, could reflect differences in regulatory mechanisms of the enzyme in different tissues. Study of patient with cytochrome c oxidase deficiency will ultimately help to clarify these issues.

\section{$\begin{array}{lllll}H & L & M & K & B\end{array}$}

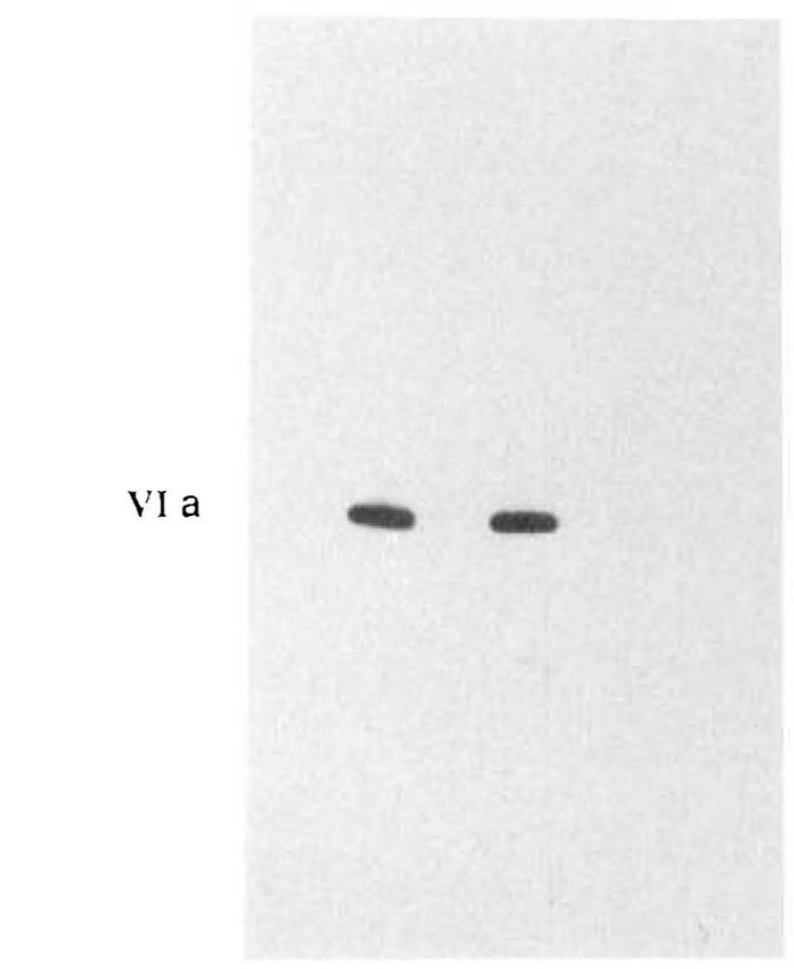

Fig. 6. Western blot showing reaction of $\mathrm{MAb}$ to the 11 form of beef heart subunit Vla with cylochrome ce oxidase from bect heart (II), liver $(L)$, skeletal muscle $(M)$, kidney $(K)$, and brain ( $B)$. Fach lane was loaded with $25 \mu \mathrm{g}$ of enzyme. Ilectrophoresis was performed as described in Figure 1, and polypeptides transferred to nitrocellulose membranes according to Towbin at al. (21). Binding of primary antibody was detected by reaction with alkaline phosphatase conjugated goat antimouse $\lg$ (; antibodies. 


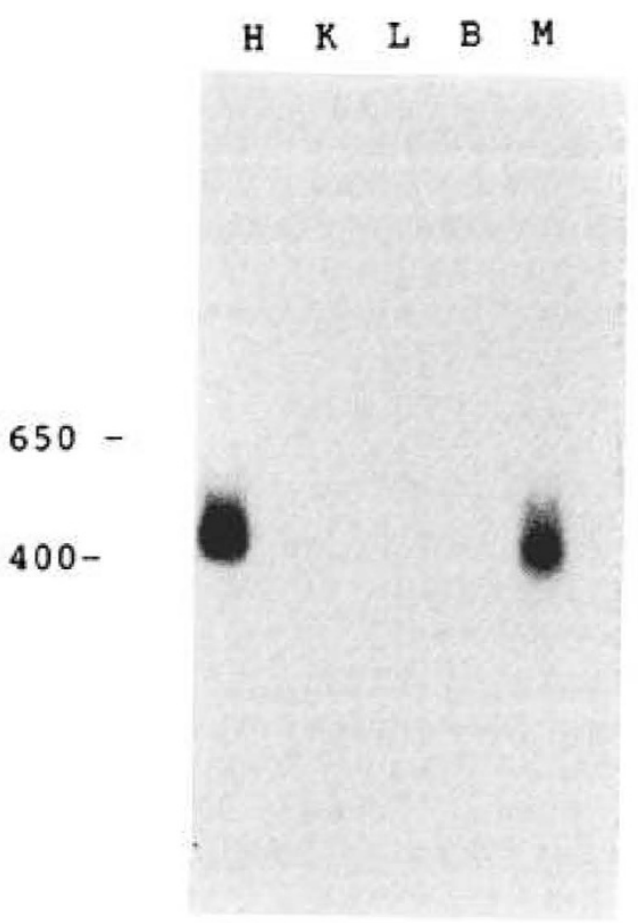

A

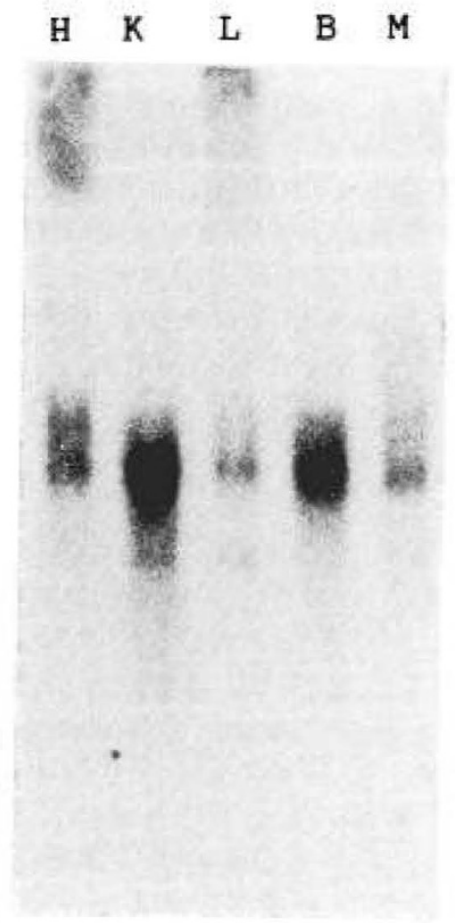

B

Fig. 7. Northern blot showing the pattern of transcription for the heart and liver forms of cytochrome $c$ oxidase subunit VIII in various beef tissues. $A, 20 \mu \mathrm{g}$ of total RNA from bovine heart $(H)$, kidney $(K)$, liver $(L)$, brain $(B)$, and skeletal muscle $(M)$ was separated through a $1.5 \%$ agarose denaturing gel containing $2 \mathrm{M}$ formaldehyde, and transferred to a nylon filter as described (20). The blot was probed with high sp act antisense RNA transcripts synthesized in vitro with T7 or SP6 RNA polymerase from pGEM-3Z (Promega Corporation, Madison, WI) vectors containing the cDNA for the heart form of bovine subunit VIII. Hybridization and washing were performed as described (20) and the washed membrane exposed at $-70^{\circ} \mathrm{C}$ to Kodak XAR-5 film for 7-10 d in the presence of a Cronex intensifying screen. B, identical blot probed with a 120 -bp Ncol generated fragment for the liver form of bovine subunit VIII. Relative sizes of the hybridizing RNA species are shown. Reproduced from J Biol Chem 20 , with permission.

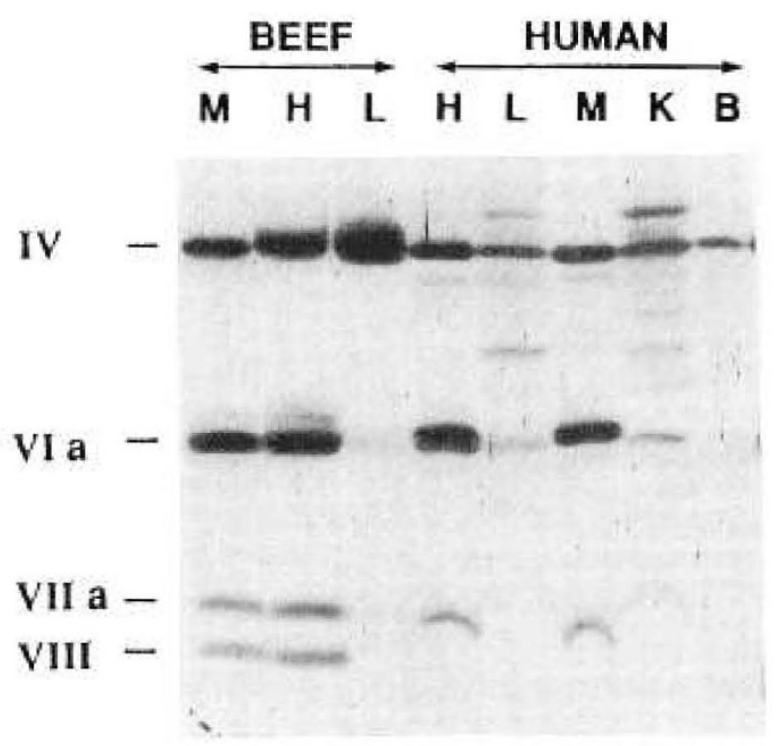

Fig. 8. Western blot showing reaction of polyclonal antibodies to beef heart cytochrome c oxidase subunits IV, VIa, VIIa, and VIII with beef skeletal muscle mitochondria $(M, 20 \mu \mathrm{g})$, heart $(H, 3.0 \mu \mathrm{g})$, and liver $(L$, $3.0 \mu \mathrm{g})$ cytochrome c oxidase and human heart $(H, 90 \mu \mathrm{g})$, liver $(L, 200$ $\mu \mathrm{g})$, skeletal muscle $(M, 100 \mu \mathrm{g})$, kidney $(K, 160 \mu \mathrm{g})$, and brain $(B, 200$ $\mu \mathrm{g})$ mitochondria. Subunits were separated on an $18.5 \%$ gel containing $6 \mathrm{M}$ urea (9), blotted onto nitrocellulose (21), and bound antibodies visualized by reaction with avidin-biotinylated alkaline phosphatase complex bound to biotinylated protein $A$.

\section{VARIABLE PRESENTATIONS OF PATIENTS WITH CYTOCHROME C OXIDASE DEFICIENCY IN RELATION TO TISSUE SPECIFICITY OF ENZYME}

From a clinical standpoint, to what extent can our understanding of tissue specificity explain the variability in severity and tissue distribution of mitochondrial diseases caused by cytochrome $\mathrm{c}$ oxidase dysfunction? If a correlation can be made between the tissue distribution of disease and the tissue distribution of isoforms of the enzyme, then the molecular analysis of a variety of mitochondrial diseases will be greatly facilitated.

The many and varied clinical phenotypes associated with cytochrome c oxidase deficiency have recently been discussed (5). For the purposes of this review, they can be divided into two major categories: multisystem diseases such as myoclonus epilepsy with ragged red fibers, Leigh's syndrome (subacute necrotizing encephalomyelopathy), or Kearns-Sayre syndrome, and diseases confined to one or a few tissues, such as progressive external ophthalmoplegia or fatal infantile mitochondrial myopathy with lactic acidosis.

In Kearns-Sayre syndrome, which is almost always sporadic, and in some patients with progressive external ophthalmoplegia, deletions of mtDNA have recently been described $(26,27)$. Myoclonus epilepsy with ragged red fibers, on the other hand, frequently shows a maternal inheritance pattern (28), also suggesting a defect of mtDNA in these patients. In either of these disorders, differential tissue involvement could reflect the different energy requirements, or the distribution of normal and mutant mtDNA in different tissues. Other multisystem diseases associated with cytochrome c oxidase deficiency, such as Leigh's syndrome, show an autosomal recessive pattern of inheritance, 
Table 1. Respiratory chain activities in mitochondria*

\begin{tabular}{|c|c|c|c|c|c|}
\hline & $\begin{array}{c}\mathrm{NADH}: \mathrm{O}_{2} \\
\text { oxidoreductase }\end{array}$ & $\begin{array}{c}\text { NADH:Q1 } \\
\text { oxidoreductase }\end{array}$ & $\begin{array}{l}\text { Succinate: } \\
\text { cytochrome } \\
\text { c reductase }\end{array}$ & $\begin{array}{c}\text { Succinate } \\
\text { dehydrogenase }\end{array}$ & $\begin{array}{l}\text { Cytochrome } \\
\text { c oxidase }\end{array}$ \\
\hline \multicolumn{6}{|c|}{ Skeletal muscle biopsy } \\
\hline Patient & 147 & 109 & 381 & 539 & 398 \\
\hline Controls $(n=9)$ & $\begin{array}{l}255 \pm 50 \\
(196-298)\end{array}$ & $\begin{array}{l}173 \pm 36 \\
(107-220)\end{array}$ & $\begin{array}{l}618 \pm 172 \\
(228-822)\end{array}$ & $\begin{array}{l}606 \pm 93 \\
(461-721)\end{array}$ & $\begin{array}{l}771 \pm 250 \\
(356-1085)\end{array}$ \\
\hline \multicolumn{6}{|l|}{ Heart autopsy } \\
\hline Patient & 42 & 98 & 143 & 353 & 29 \\
\hline Controls $(n=9)$ & $\begin{array}{l}236 \pm 67 \\
(153-353)\end{array}$ & $\begin{array}{r}147 \pm 104 \\
(55-322)\end{array}$ & $\begin{array}{l}213 \pm 55 \\
(119-316)\end{array}$ & $\begin{array}{l}407 \pm 94 \\
(258-554)\end{array}$ & $\begin{array}{l}440 \pm 131 \\
(303-707)\end{array}$ \\
\hline
\end{tabular}

* Activities are expressed as $\mathrm{nmol} / \mathrm{mg}$ protein $/ \mathrm{min}$. Controls are mean $\pm \mathrm{SD}$ with range in parentheses. Mitochondria were isolated from tissues by the method of Bookelman et al. (30) after mild trypsin digestion in the case of skeletal muscle. Activities of rotenone-sensitive NADH:oxygen oxidoreductase (31), NADH: ubiquinone oxidoreductase (31), succinate:cytochrome c reductase (32), succinate dehydrogenase (32), and cytochrome c oxidase (33) were measured according to published procedures.

which could be explained by a mutation of a nuclear encoded subunit that is not expressed in a tissue-specific manner.

Diseases in which cytochrome c oxidase deficiency is limited to one or a few tissues, on the other hand, are the ones most likely to result from mutation of a tissue-specific subunit. Included in this group are patients with severe infantile mitochondrial myopathy and lactic acidosis. In some cases, the disease is spontaneously reversible, suggesting that developmentally regulated isoforms of cytochrome c oxidase may also exist, although no evidence for such isoforms has been obtained in mammalian tissues (29). In other cases, the disease is fatal; it may be restricted to skeletal muscle or it may be associated with renal dysfunction or cardiomyopathy. A patient that we have studied recently, in which cardiac manifestations were predominant, is described briefly below.

Fatal cardiomyopathy associated with cytochrome c oxidase deficiency: case report. N.J. presented soon after birth with hypotonia, seizures, and lactic acidosis, after a pregnancy in which decreased fetal movement was noted. An echocardiogram, normal on $\mathrm{d} 6$, showed massive biventricular hypertrophy by $\mathrm{d}$ 22. She died $2 \mathrm{~d}$ later of cardiac failure.

Muscle biopsies at 8 and $21 \mathrm{~d}$ were normal by light and electron microscopy. Liver histology was also normal. At autopsy, electron microscopy of cardiac muscle showed displacement of myofibrils by greatly increased numbers of mitochondria, many of which had abnormal shapes and abnormally arranged cristae. Cytochrome c oxidase activity was severely reduced in heart and was in the low-normal range in muscle (Table 1). It was also diminished in liver and kidney $(<25 \%$ of controls, data not shown). The low activity of $\mathrm{NADH}: \mathrm{O}_{2}$ oxidoreductase in heart presumably reflects the cytochrome c oxidase deficiency. Cytochrome spectra revealed complete absence of cytochrome $\mathrm{aa}_{3}$ in heart mitochondria, whereas it was $37 \%$ of normal in skeletal muscle.

Western blot analysis (Fig. 9) showed marked deficiency of cytochrome c oxidase subunits II, VIb, VIc, and VIIa, as well as III and VIa (not shown), with relative sparing of subunits IV and $\mathrm{Va}$ in the patient's heart, whereas in skeletal muscle (Fig. 10), only a mild generalized deficiency of subunits was seen.

This patient was unusual in several respects. Her clinical presentation was distinct from previously reported patients with cytochrome c oxidase deficiency, with cardiac involvement predominating and relative sparing of skeletal muscle. Although patients with fatal infantile mitochondrial myopathy may have associated cardiomyopathy, the deficiency in skeletal muscle is usually as severe or more severe than in heart $(34,35)$. Expression of the defect in liver as well as kidney is also unusual, except in Leigh's syndrome (35), and these patients do not normally present at such an early age.

The findings in this patient, and reports of variability of tissue

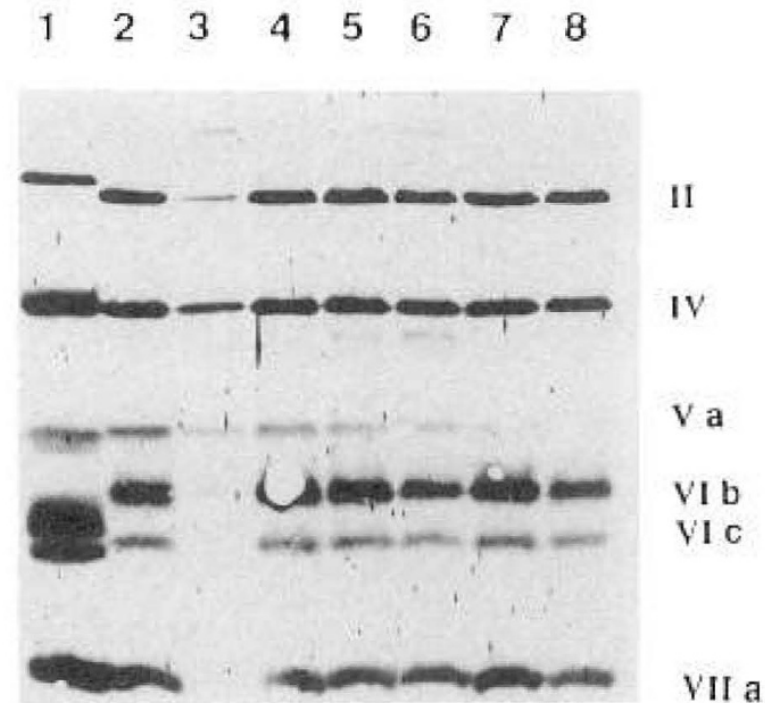

Fig. 9. Antibody binding to subunits of cytochrome $c$ oxidase in heart mitochondria from patient N.J. Lane 1, beef, $25 \mu \mathrm{g}$; lanes 2, 4, 5, 6, 7, and 8 , human controls, $120 \mu \mathrm{g}$; lane 3, patient, $120 \mu \mathrm{g}$. Conditions were as described in Figure 8.

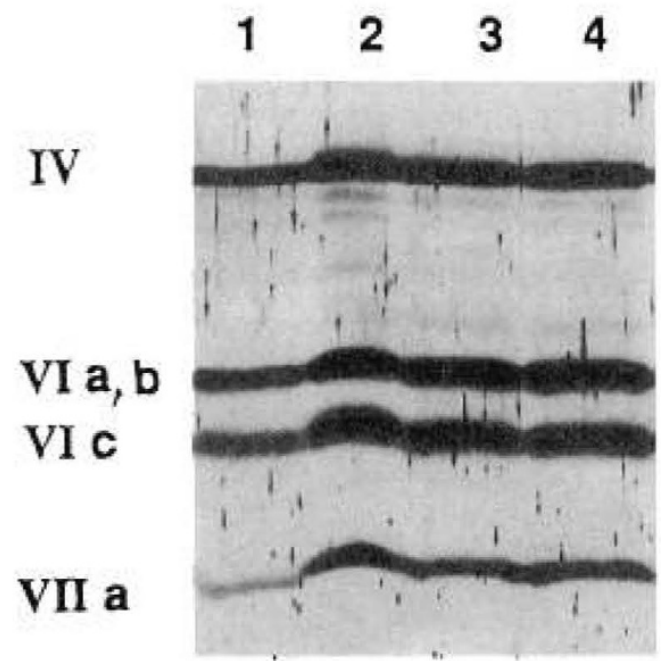

Fig. 10. Antibody binding to subunits of cytochrome $\mathrm{c}$ oxidase in skeletal muscle mitochondria from patient N.J. Lane 1, patient, $100 \mu \mathrm{g}$; lanes 2, 3, and 4, human controls, $100 \mu \mathrm{g}$. Conditions were as described in Figure 8. 
involvement in other patients with mitochondrial myopathy due to cytochrome c oxidase deficiency, suggest an important feature of tissue specificity not apparent from structural studies described in previous sections: there may be considerable plasticity of tissue specificity of this enzyme in humans. Indeed, one or more tissues may show variability, and even co-expression of the cytochrome $c$ oxidase isoforms that are present. Moreover, we speculate that the relative amounts of the various isoforms may fluctuate with developmental stage and other cellular signals, and these amounts may accommodate to some degree to compensate for defects in any particular subunit isoform.

\section{SUMMARY AND CONCLUSIONS}

In this review, we have summarized the structure, function, and biogenesis of mammalian cytochrome $\mathrm{c}$ oxidase, presented data supporting the existence of tissue-specific isoforms of several subunits, reviewed possible mechanisms underlying the abnormal phenotypes of patients with cytochrome c oxidase deficiency, and discussed the insights that such patients provide about regulation of the synthesis of different forms of this enzyme.

It is clear that tissue-specific isoforms of several subunits of cytochrome $\mathrm{c}$ oxidase do exist in mammals, including humans. However, the lack of conservation of the patterns of tissue specificity between species leaves open the question of the functional importance of these patterns.

It is likely that a mutation of one of the tissue-specific isoforms of cytochrome $c$ oxidase underlies the tissue-specific expression of this enzyme deficiency in some patients. However, in most patients studied to date, the phenotype does not appear to correlate with isoform distribution as we understand it, and much more needs to be learned about the expression of the human enzyme before such correlations can be made. In particular, it is important to understand the regulation of synthesis of the various isoforms.

Finally, description of the molecular defect in more than a few patients with cytochrome $\mathrm{c}$ oxidase deficiency will likely require a substantial collaborative effort between clinicians, biochemists, and molecular biologists. Exchange of tissues, antibodies, and cDNA between different laboratories will ensure the best use of available resources, and accelerate progress toward understanding the molecular mechanisms that give rise to disorders of the respiratory chain in humans.

\section{REFERENCES}

1. DiMauro S. Bonilla E. Zeviani M, Nakagawa M, DeVivo DC 1985 Mitochondrial myopathies. Ann Neurol 17:521-538

2. Morgan-Hughes JA. Schapira AHV, Cooper JM, Clark JB 1988 Molecular defects of NADH-ubiquinone oxidoreductase (complex I) in mitochondrial diseases. J Bioenerg Biomembr 20:365-382

3. Rivner MH, Shamsnia M, Swift TR. Trefz J, Roesel RA, Carter AL, Yanamura W, Hommes FA 1989 Kearns-Sayre syndrome and complex II deficiency. Neurology 39:693-696

4. Kennaway NG 1988 Defects in the cytochrome $b c_{1}$ complex in mitochondrial diseases. J Bioenerg Biomembr 20:325-352

5. DiMauro S. Zeviani M, Rizzuto R, Lombes A. Nakase H. Bonilla E. Miranda A. Schon E 1988 Molecular defects in cytochrome oxidase in mitochondrial diseases. J Bioenerg Biomembr 20:353-364

6. Capaldi RA, Gonzalez-Halphen D. Zhang Y-Z, Yanamura W 1988 Complexity and tissue specificity of the mitochondrial respiratory chain. J Bioenerg Biomembr 20:291-311

7. Clay VJ, Ragan Cl 1988 Evidence for the existence of tissue specific isoenzymes of mitochondrial NADH dehydrogenase. Biochem Biophys Res Commun 157:1423-1428

8. Capaldi RA, Takamiya S, Zhang Y-Z. Gonzalez-Halphen D. Yanamura W 1987 Structure of cytochrome-c oxidase. Curr Top Bioenerg 15:91-112

9. Kadenbach B, Jarausch J, Hartmann R, Merle P 1983 Separation of mammalian cytochrome $\mathrm{c}$ oxidase into 13 polypeptides by a sodium dodecyl sulfate-gel electrophoretic procedure. Anal Biochem 129:517-521

10. Capaldi RA, Gonzalez-Halphen D, Takamiya S 1986 Sequence homologies and structural similarities between the polypeptides of yeast and beef heart cytochrome c oxidase. FEBS Lett 207:11-17

11. Capaldi RA. Hayashi H 1972 The polypeptide composition of cytochrome oxidase from beef heart mitochondria. FEBS Lett 26:261-263

12. Takamiya S, Yanamura W, Capaldi RA, Kennaway NG, Bart R, Sengers RCS. Trijbels JMF. Ruitenbeek W 1986 Mitochondrial myopathies involving the respiratory chain: a biochemical analysis. Ann NY Acad Sci 488:33-43

13. Kadenbach B, Buge U, Jarausch J, Merle P 1981 Composition and kinetic properties of cytochrome c oxidase from higher eucaryotes. In: Palmieri F. Quaglierello E, Siliprandi N, Slater C (eds) Vectorial Reactions in Electron and Ion Transport in Mitochondria and Bacteria. Elsevier. Amsterdam, pp $11-23$

14. Merle P. Kadenbach B 1980 On the heterogeneity of vertebrate cytochrome c oxidase polypeptide chain composition. Hoppe-Seylers Z Physiol Chem 361:1257-1259

15. Stroh A, Kadenbach B 1986 Tissue-specific and species-specific distribution of -SH groups in cytochrome c oxidase subunits. Eur J Biochem 156:199-204

16. Schlerf A, Droste M, Winter M, Kadenbach B 1988 Characterization of two different genes (cDNA) for cytochrome c oxidase subunit Vla from heart and liver of the rat. EMBO J 7:2387-239

17. Kuhn-Nentwig L, Kadenbach B 1985 Isolation and properties of cytochrome c oxidase from rat liver and quantification of immunological differences between isozymes from various rat tissues with subunit-specific antisera. Eur J Biochem 149:147-158

18. Matsudaira P 1987 Sequence from picomole quantities of proteins electroblotted onto polyvinylidene difluoride membranes. J Biol Chem 262:1003510038

19. Yanamura W, Zhang Y-Z, Takamiya S, Capaldi RA 1988 Tissue-specific differences between heart and liver cytochrome c oxidase. Biochemistry 27:4909-4914

20. Lightowlers R, Ewart G, Aggeler R, Zhang Y-Z, Calavetta L, Capaldi RA 1989 Isolation and characterization of the cDNAs encoding two isoforms of subunit CIX of bovine cytochrome c oxidase. J Biol Chem 265:2677-2681

21. Towbin H. Staehelin T, Gordon J 1979 Electrophoretic transfer of proteins from polyacrylamide gels to nitrocellulose sheets: procedure and some applications. Proc Natl Acad Sci USA 76:4350-4354

22. van Kuilenburg ABP, Muijsers AO, Demol H. Dekker HL, Van Beeumen JJ 1988 Human heart cytochrome c oxidase subunit VIII: purification and determination of the complete amino acid sequence. FEBS Lett 240:127132

23. Rizzutto R, Nakase H, Darras B, Fabrizi GM. Mengel T. Walsh F. Kadenbach B. DiMauro S, Franke U, Schon E 1989 A gene specifying subunit VIl of human cytochrome coxidase is localized to chromosome 11 and is expressed in both muscle and non-muscle tissues. J Biol Chem 264:10595-10600

24. Kadenbach B. Kuhn-Nentwig L. Buge U 1987 Evolution of a regulatory enzyme: cytochrome-c oxidase (complex IV). Curr Top Bioenerg 15:113161

25. Bisson R, Schiavo G, Montecucco C 1987 ATP induces conformationa changes in mitochondrial cytochrome c oxidase: effect on the cytochrome $c$ binding site. J Biol Chem 262:5992-5998

26. Holt IJ, Harding AE, Morgan-Hughes JA 1988 Deletions of muscle mitochondrial DNA in patients with mitochondrial myopathies. Nature 331:717-719

27. Moraes CT, DiMauro S, Zeviani M. Lombes A. Shanske S. Miranda AF, Nakase H. Bonilla E, Werneck LC, Servidei S 1989 Mitochondrial DNA deletions in progressive external ophthalmoplegia and Kearns-Sayre syndrome. N Engl J Med 320:1293-1299

28. Rosing HS, Hopkins LC. Wallace DC. Epstein CM, Weidenheim K 1985 Maternally inherited mitochondrial myopathy and myoclonic epilepsy. Ann Neurol 17:228-237

29. Takamiya S, Lindorfer MA, Capaldi RA 1987 Purification of all thirteen polypeptides of bovine heart cytochrome c oxidase from one aliquot of enzyme: characterization of bovine fetal heart cytochrome oxidase. FEBS Lett 218:277-282

30. Bookelman H, Trijbels JMF Sengers RCA, Janssen AJM, Veerkamp JH, Stadhouders AM 1978 Pyruvate oxidation in rat and human skeletal muscle mitochondria. Biochem Med 20:395-403

31. Fischer JC, Ruitenbeek W, Trijbels JMF, Veerkamp JH, Stadhouders AM Sengers RCA, Janssen AJM 1986 Estimation of NADH oxidation in human skeletal muscle mitochondria. Clin Chim Acta 155:263-274

32. Fischer JC. Ruitenbeek W, Berden JA, Trijbels JMF, Veerkamp JH, Stadhouders AM, Sengers RCA. Janssen AJM 1985 Differential investigation of the capacity of succinate oxidation in human skeletal muscle. Clin Chim Acta 153:23-36

33. Wharton DC, Tzagoloff A 1967 Cytochrome oxidase from beef heart mitochondria. Methods Enzymol 10:245-250

34. Zeviani M, Van Dyke DH, Servidei S. Bauserman SC. Bonilla E, Beaumont ET, Sharda J, VanderLaan K. DiMauro S 1986 Myopathy and fatal cardiomyopathy due to cytochrome c oxidase deficiency. Arch Neurol 43:11981202

35. DiMauro S, Servidei S, Zeviani M. DiRocco M. DeVivo DC, DiDonato S, Uziel G, Berry K. Hoganson G. Johnsen SD, Johnson PC 1987 Cytochrome c oxidase deficiency in Leigh syndrome. Ann Neurol 22:498-506 